\title{
elsevier_YJADO_1694
}

\section{Development of emotional autonomy from adolescence to young adulthood in Spain}

Águeda Parra*

aparra@us.es

Alfredo Oliva

oliva@us.es

Inmaculada Sánchez-Queija

queija@us.es

Department of Developmental Psychology, University of Seville, C/ Camilo José Cela, s/n, 41018 Seville, Spain

*Corresponding author. Tel.: +34 955 420527; fax: +34 954559544 .

${ }^{1}$ Tel.. +34 954 557695; fax: +34 954559544

\section{Abstract}

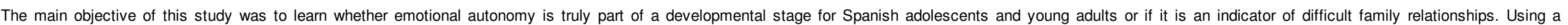

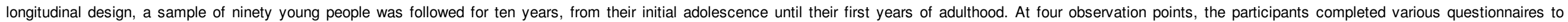

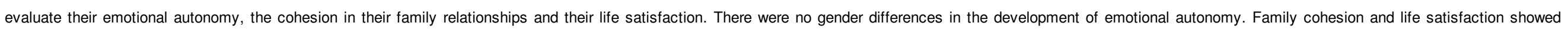

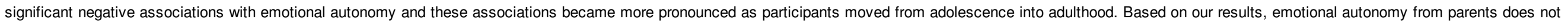
seem to be a developmental stage taking place during adolescence, but rather, an indicator of difficult family relationships.

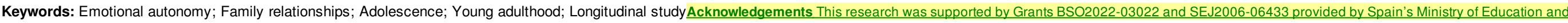
Science.

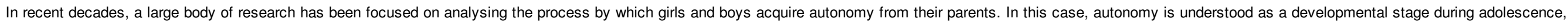

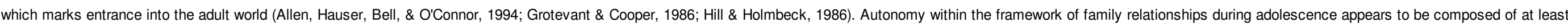

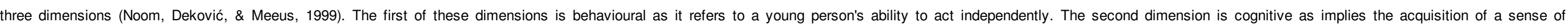

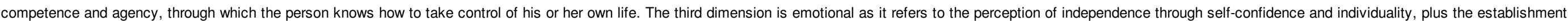
of emotional bonds that are more symmetrical than those seen in their relationship during childhood.

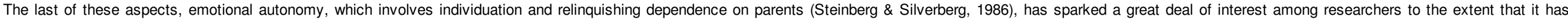

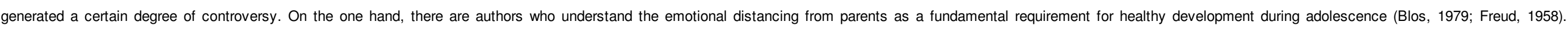

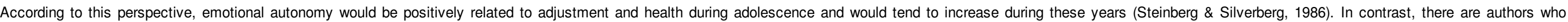

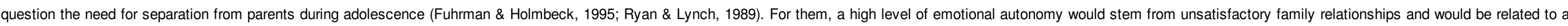

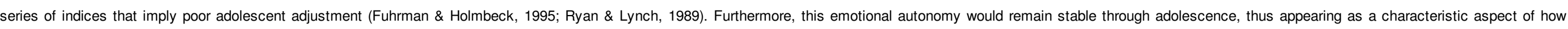
certain families function rather than a feature of the normal state of the relationships between parents and adolescents

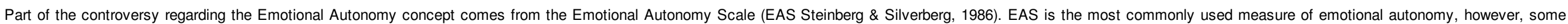

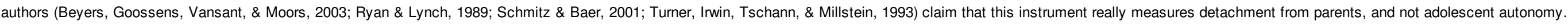




\section{elsevier_YJADO_1694}

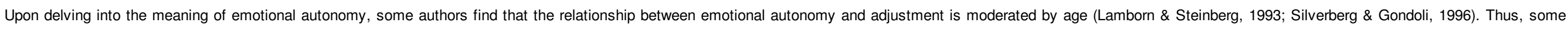

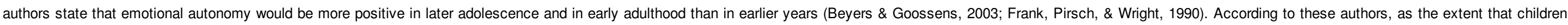

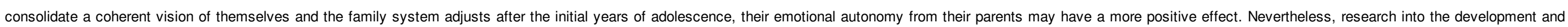
meaning of emotional autonomy during early adulthood is scarce (Arnett, 2000, 2006; Beyers \& Goossens, 2003; Kins, Beyers, \& Soenens, 2013; Kins, Soenens, \& Beyers, 2011).

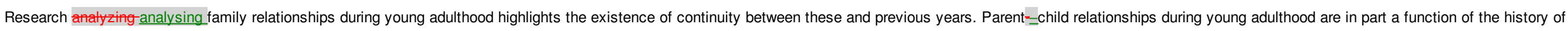

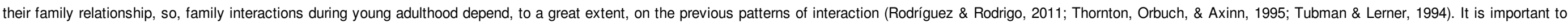

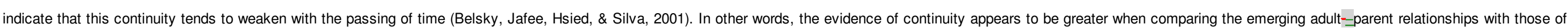

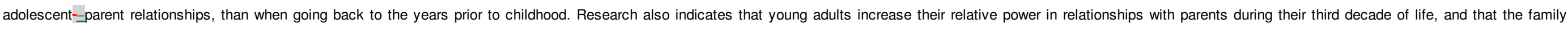
relationships usually improve during these years, with a lower conflict rate (Noack \& Buhl, 2005).

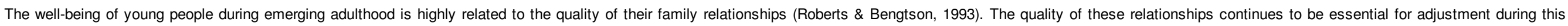

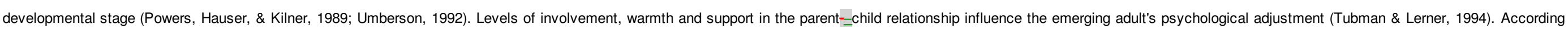

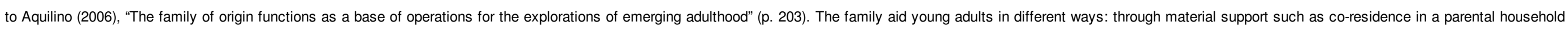
or parental financial subsidies, but also through the availability of parents as a source of comfort and guidance for young adults.

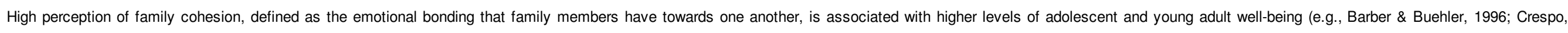

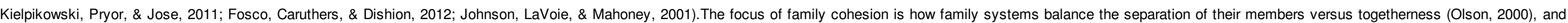

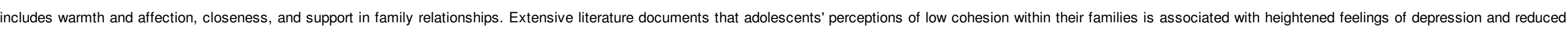

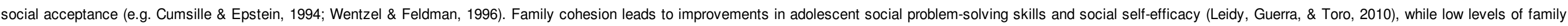

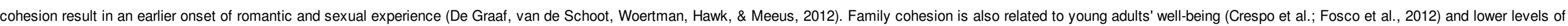

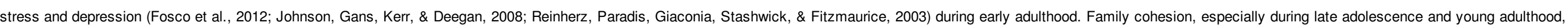

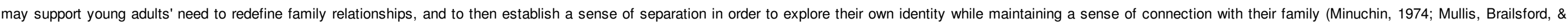
Mullis, 2003).

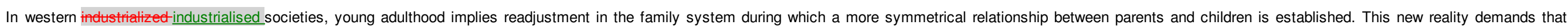

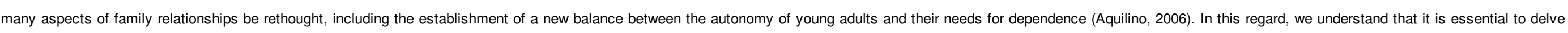

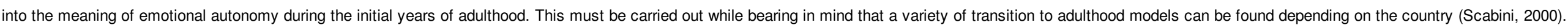

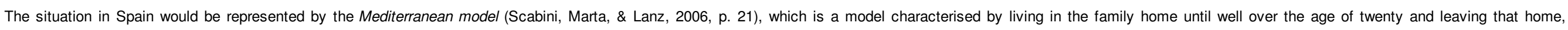

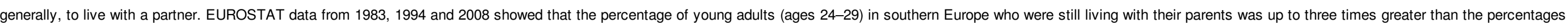

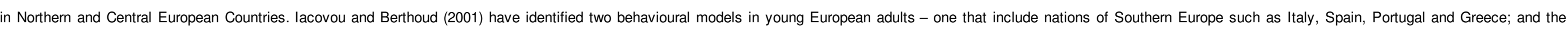

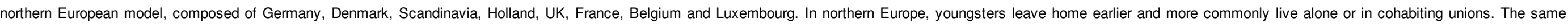

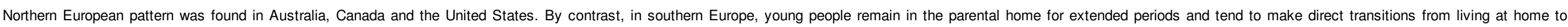

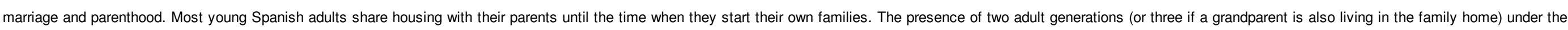

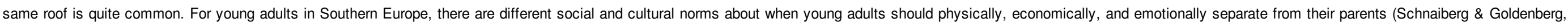

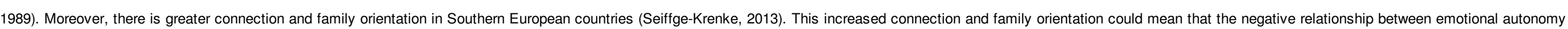
and family relationships is even greater in Southern European countries such as Spain.

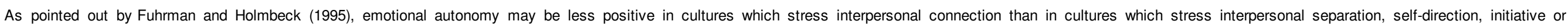

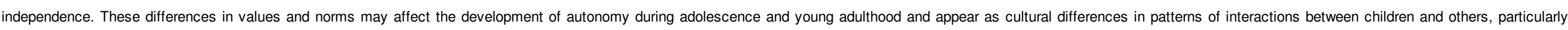

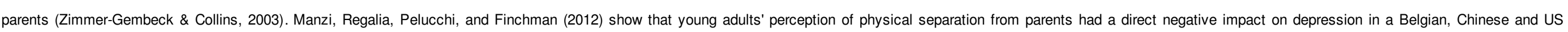




\section{elsevier_YJADO_1694}

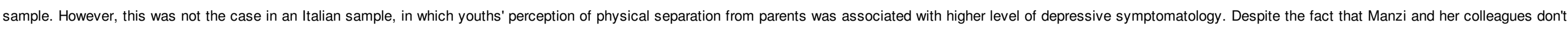

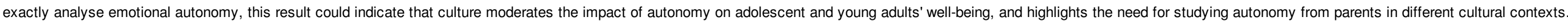

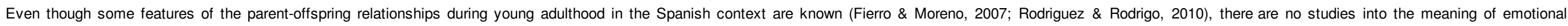

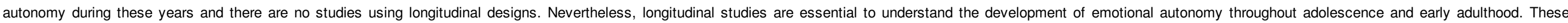

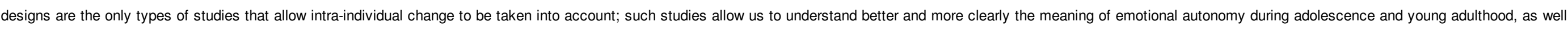
as its relationship with other family and personal adjustment variables.

\section{The present study}

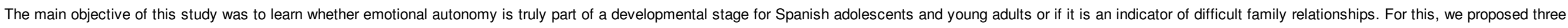

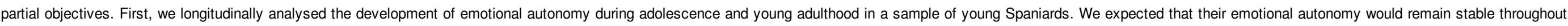

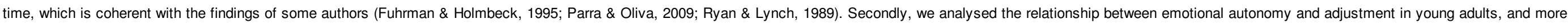

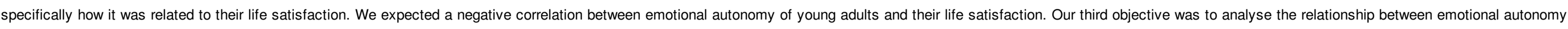

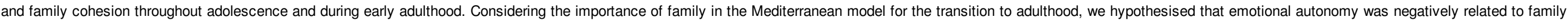
cohesion. Finally, we expected that family cohesion would lead to changes in emotional autonomy throughout adolescence and young adulthood.

\section{Method}

\section{Participants}

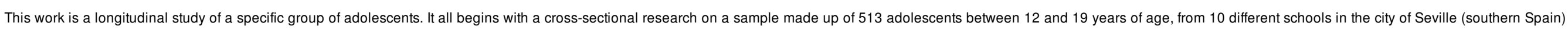

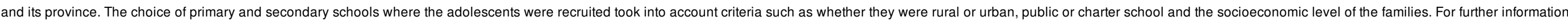
about the sampling procedure, see Oliva and Parra (2001) and Parra and Oliva (2002).

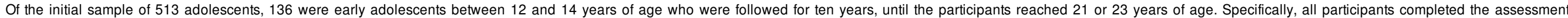

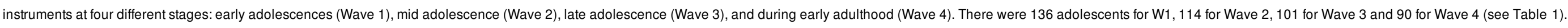

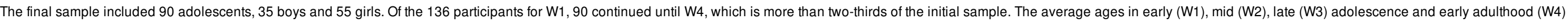
were: $\mathrm{W} 1(M a g e=13.11 ; \mathrm{SD}=.44) ; \mathrm{W} 2($ Mage $=15.38 ; \mathrm{SD}=.56) ; \mathrm{W} 3($ Mage $=17.85 ; \mathrm{SD}=.52) ; \mathrm{W} 4($ Mage $=21.73 ; \mathrm{SD}=.61)$

Table 1 Frequencies and percentages of participants in each wave of the study.

\begin{tabular}{|c|c|c|c|c|}
\hline & $\begin{array}{c}\text { W1 } \\
n(\%)\end{array}$ & $\begin{array}{c}\text { W2 } \\
n(\%)\end{array}$ & $\begin{array}{c}\text { W3 } \\
n(\%)\end{array}$ & $\begin{array}{c}\text { W4 } \\
n(\%)\end{array}$ \\
\hline Boys & $58(42.6 \%)$ & $46(40.4 \%)$ & $38(37.6 \%)$ & $35(38.9 \%)$ \\
\hline Girls & 78 (57.4\%) & $68(59.6 \%)$ & $63(62.4 \%)$ & $55(61.1 \%)$ \\
\hline Total & 136 & 114 & 101 & 90 \\
\hline
\end{tabular}

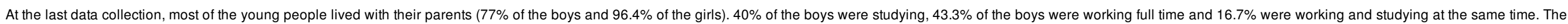

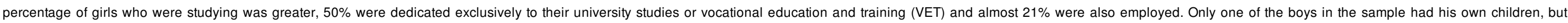
continued studying, living with his parents and generally leading a life similar to the rest of the boys in the sample. None of the girls had been mothers when the data was collected.

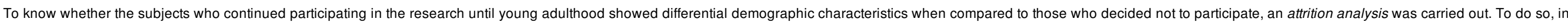

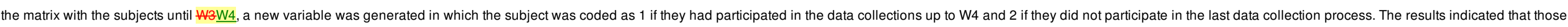

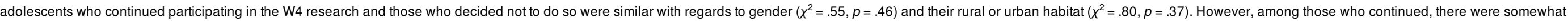




\section{elsevier_YJADO_1694}

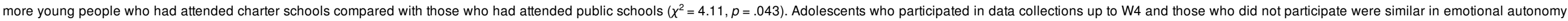
$F(1,127)=.11, p=.75$; life Satisfaction $F(1,130)=2.60, p=.11$ and family cohesion $F(1,124)=4.89, p=.08$.

\section{Measures}

\section{Background variables}

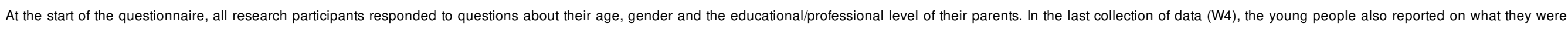
currently doing (working and/or studying), with whom they lived (with parents, with a partner, with flatmates, alone ...) and whether they had children.

\section{Emotional autonomy}

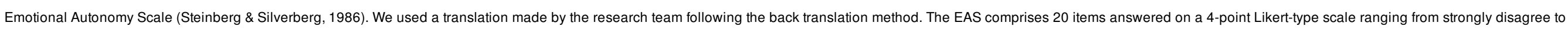

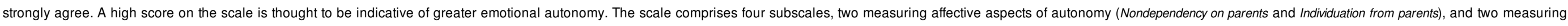

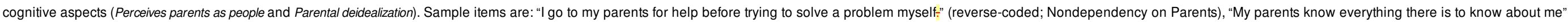

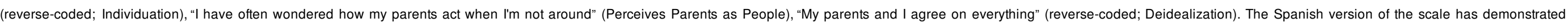

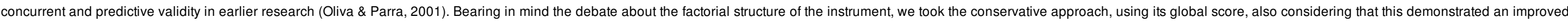
reliability and validity indicator than the 4 sub-scales separately. The scale's reliability for each of the measuring times was as follows: Cronbach's alpha $=.66, .75, .79$, and .81, in W1, W2, W3 and W4 respectively.

\section{Family cohesion}

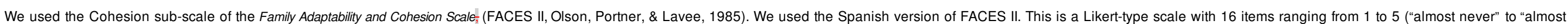

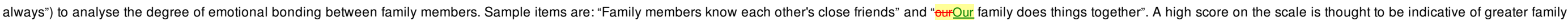

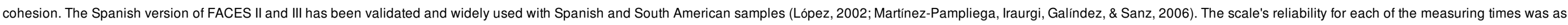
follows: Cronbach's alpha $=.69, .84, .87$, and .89 , in W1, W2, W3 and W4 respectively.

\section{Life satisfaction}

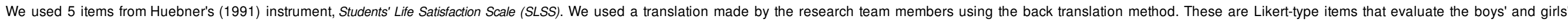

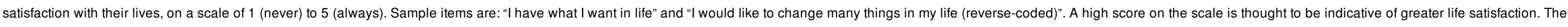

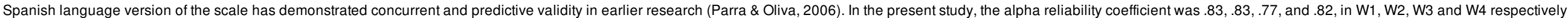

\section{Procedure}

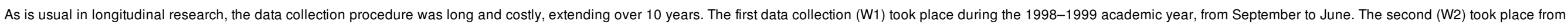
September 2000 to June 2001, the third (W3) from September 2002 to June 2003 and the fourth (W4) between the end of 2007 and the beginning of 2008.

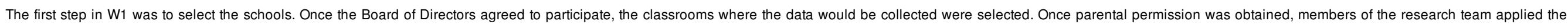
questionnaires anonymously and collectively. To facilitate the subsequent follow-up, each participant was given a numeric identifier.

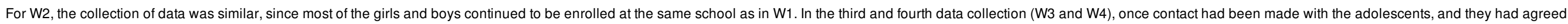

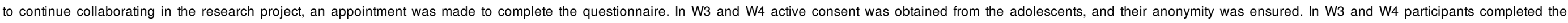
questionnaires individually or collectively in the researchers' office.

\section{Plan of data analysis}

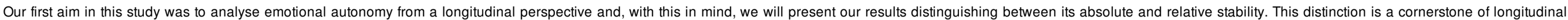




\section{elsevier_YJADO_1694}

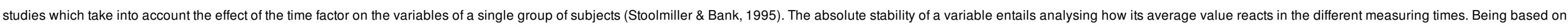

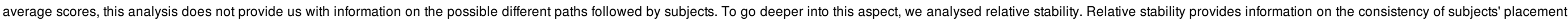
regarding their reference group. The procedure most commonly used to measure relative stability is based on the Pearson correlation coefficients between different measuring times (Alder \& Scher, 1994).

To analyse absolute stability of Emotional Autonomy we carried out an ANOVA for repeated measures with one between-subjects factor (gender) and one within-subject factor (waves)!

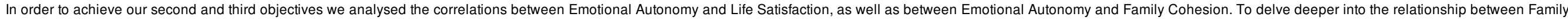

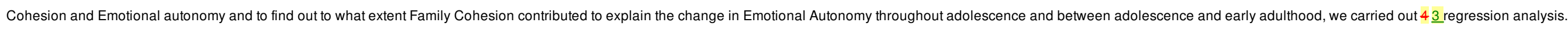

\section{Results}

Mean, standard deviation and range of variables of the study for each of the measurement points appear in Table 2.

Table 2 Means and standard deviation of the study variables in wave 1, 2, 3, and 4.

Emotional autonomy

$52.37(6.39)$

$38-68$

$$
\text { 35-69 }
$$

52.32 (6.7)

$34-75$

$56.75(9.88)$

24-77

$18.1(4.2)$

$5-25$

Wave 3

Mean (SD)

53.4 (7.3)

55.61 (10.46)

29-79

17.96 (3.96)

36-76

$57.89(10.15)$

27-79

Life satisfaction

19.2 (3.6)

9-25

49.8 (7.5)

29-64
6-25

19.55 (3.55)

8-25

\section{Absolute stability of emotional autonomy}

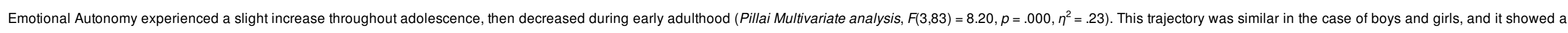

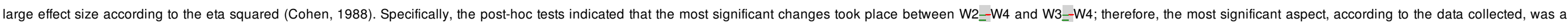
decrease in the levels of eEmotional zAutonomy at the end of adolescence.

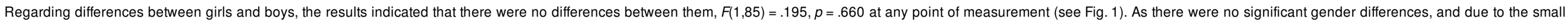
size of the sample, the following analyses were carried out without differentiating between boys and girls. 


\section{elsevier_YJADO_1694}

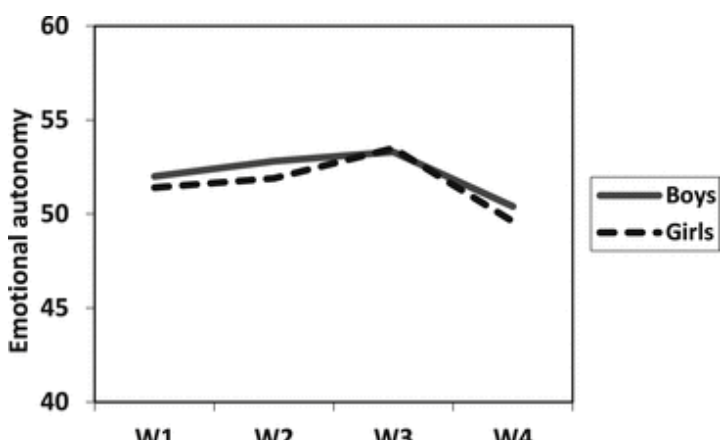

\section{Relative stability of emotional autonomy}

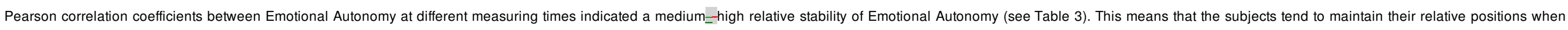
compared with the average at a different point of the observations.

Table 3 Relative stability of emotional autonomy.

\begin{tabular}{|c|c|c|c|c|}
\hline & 1 & 2 & 3 & 4 \\
\hline 1. Emotional autonomy W1 & - & $.44^{\star \star}$ & $.44^{\star *}$ & $.30^{\star *}$ \\
\hline 2. Emotional autonomy W2 & & - & $.70^{\star \star}$ & $.54^{\star \star}$ \\
\hline 3. Emotional autonomy W3 & & & - & $.65^{\star \star}$ \\
\hline 4. Emotional autonomy W4 & & & & - \\
\hline
\end{tabular}

Note. ${ }^{*} p<.05 ;{ }^{* *} p<.01$.

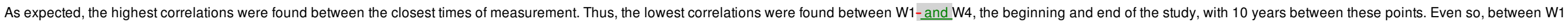
and W4 the correlations were statistically significant. According to our results, the period of greatest uncertainty was found between initial and mid-adolescence (W1_W2).

\section{Emotional autonomy and life satisfaction}

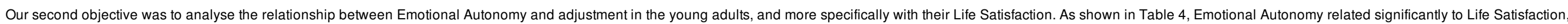
but in negative terms. The correlations increased over time, and the correlation between both variables in W1 was much less than in W3 or W4. However, this difference was not statistically significant, $z=1.64, p=.10$ (Preacher, 2002).

Table 4 Correlations among emotional autonomy and life satisfaction.

\begin{tabular}{|c|c|c|c|c|}
\hline & \multicolumn{4}{|c|}{ Life satisfaction } \\
\hline & W1 & W2 & W3 & W4 \\
\hline Emotional autonomy W1 & -.15 & -.07 & -.11 & -.16 \\
\hline Emotional autonomy W2 & & $-.25^{\star}$ & $-.18^{+}$ & $-.32^{* \star}$ \\
\hline Emotional autonomy W3 & & & $-.35^{\star \star}$ & $-.40^{\star \star}$ \\
\hline Emotional autonomy W4 & & & & $-.38^{\star *}$ \\
\hline
\end{tabular}




\section{elsevier_YJADO_1694}

Note. ${ }^{+} p<.1 ;{ }^{*} p<.05 ;{ }^{* *} p<.01$

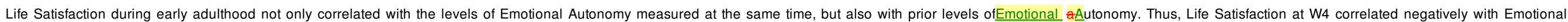
Autonomy at W4, W3 and W2.

\section{Emotional autonomy and family cohesion}

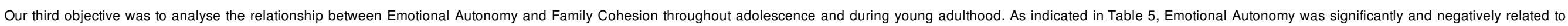

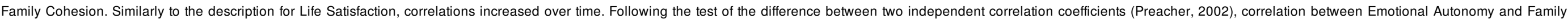

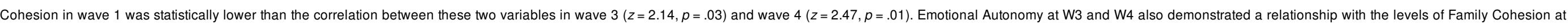
previous times (W2, W3, W4).

Table 5 Correlations among emotional autonomy and family cohesion.

\begin{tabular}{|c|c|c|c|c|}
\hline & \multicolumn{4}{|c|}{ Emotional autonomy } \\
\hline & W1 & W2 & W3 & W4 \\
\hline Cohesion W1 & $-.38^{\star *}$ & -.14 & -.06 & -.08 \\
\hline Cohesion W2 & & $-.55^{\star \star}$ & $-.43^{\star \star}$ & $-.35^{\star *}$ \\
\hline Cohesion W3 & & & $-.62^{\star \star}$ & $-.53^{\star *}$ \\
\hline Cohesion W4 & & & & $-.65^{\star \star}$ \\
\hline
\end{tabular}

Note. ${ }^{*} p<.05 ;{ }^{*} p<.01$

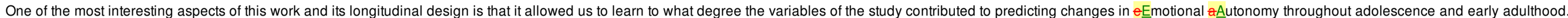

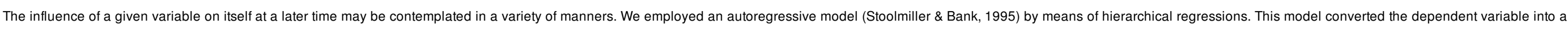

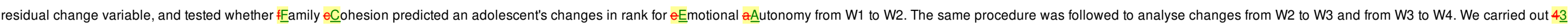

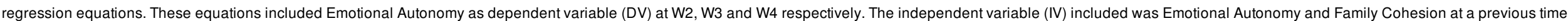

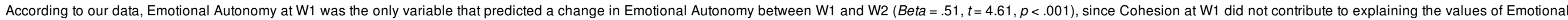
Autonomy at W2 (Beta $=.03, t=.26, p=.797$ ) once the Emotional Autonomy at W1 was included in the equation $\left(R^{2}\right.$ of the model $=.20$ ).

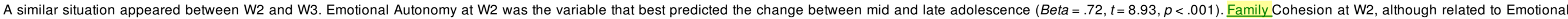
Autonomy at W3 (6), did not contribute to explaining the change between W2 and W3 (Beta $=-.08, t=-.86, p=.390) . R^{2}$ of the model $=.48$.

Table 6 Hierarchical multiple regression analyses predicting change in emotional autonomy from W1 to W4.

Emotional autonomy W4

Step 1

.42

Emotional autonomy W3

$.65^{\star *}$

Step 2

Emotional autonomy W3 
Note. ${ }^{*} p<.05 ;{ }^{* *} p<.01$.

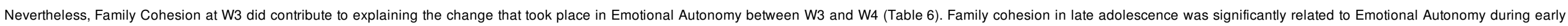

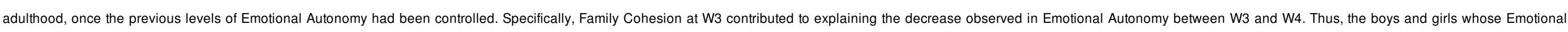
Autonomy decreased most between late adolescence and young adulthood were those who showed a greater Family Cohesion in late adolescence.

\section{Discussion}

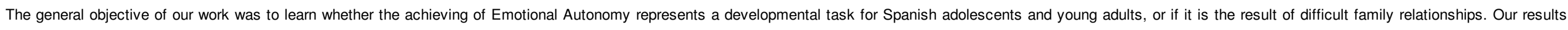
point to the second option for various reasons.

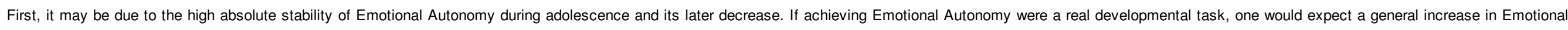

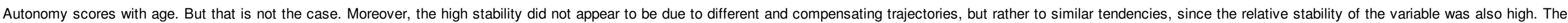

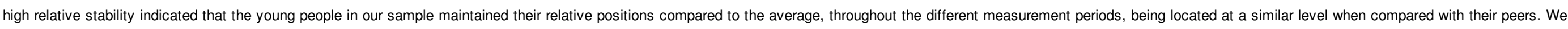

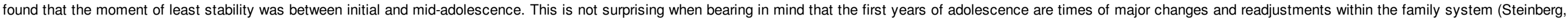
1989), which could cause fluctuations in the relative scores of the subjects when asked about their relationships with their parents.

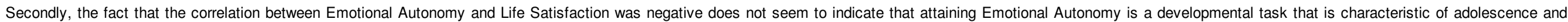

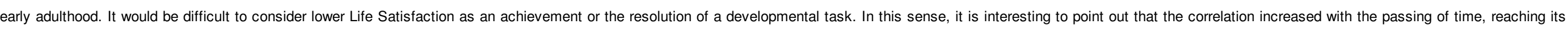

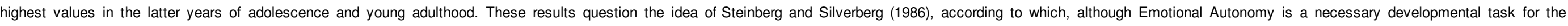

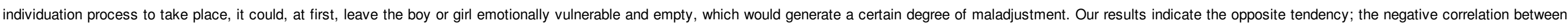
Life Satisfaction and Emotional Autonomy, far from diminishing, increased with the passing of time.

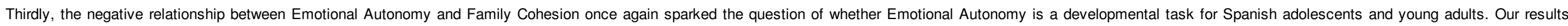

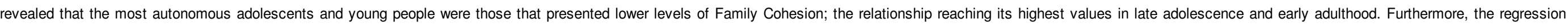

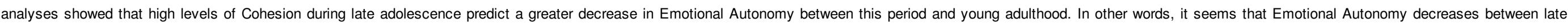

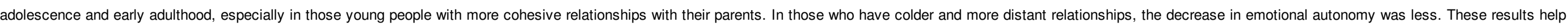

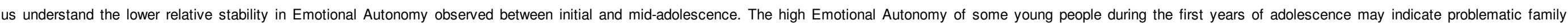

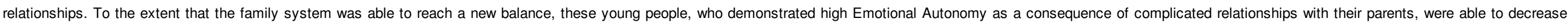
their levels of Emotional Autonomy until they reached the group average. However, there may always be adolescents and young adults with difficult family relationships, who also manifest a greater Emotional Autonomy.

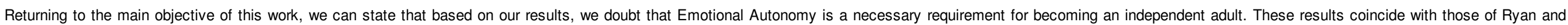

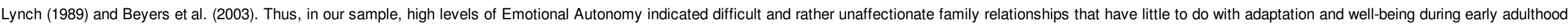

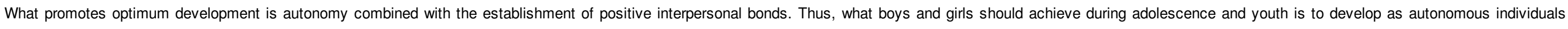
being capable of maintaining positive relationships with others, especially with their parents (Grotevant \& Cooper, 1986; Smollar \& Youniss, 1989; Umberson, 1992).

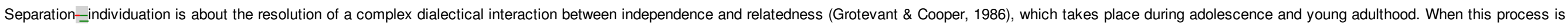

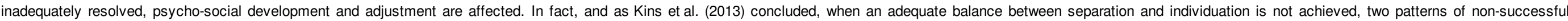

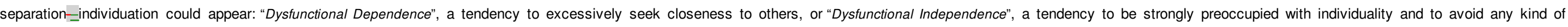

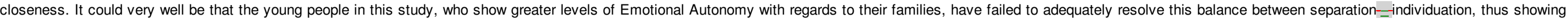
reduced Life Satisfaction and colder relationships with their parents. This, perhaps, would place them in the category of "Dysfunctional Independence" as described by Kins et al. (2013). 


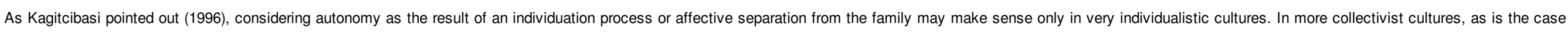

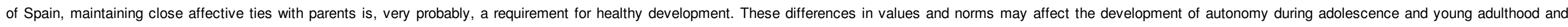
appear as cultural differences in patterns of interactions between adolescents and others, particularly parents (Zimmer-Gembeck \& Collins, 2003)

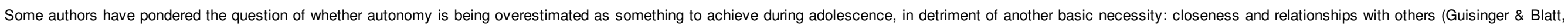

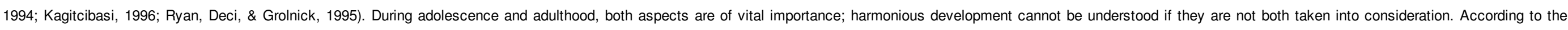

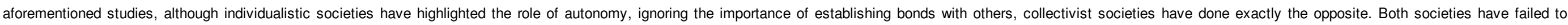

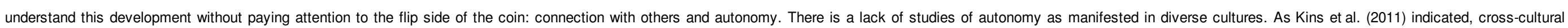
comparison studies are needed to help to clarify the role of the family process in the prediction of the adolescent and young adult autonomy process.

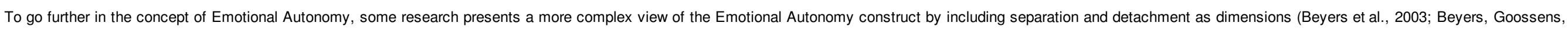

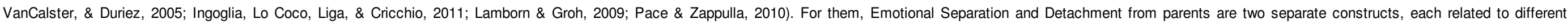

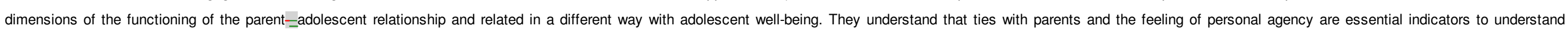
autonomy from parents.

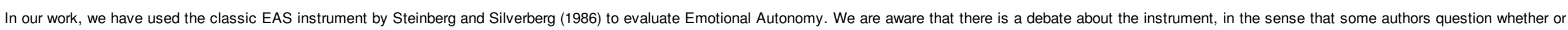

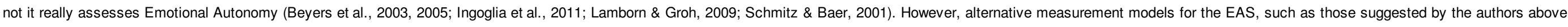

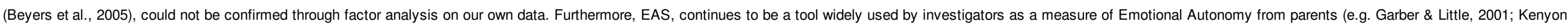

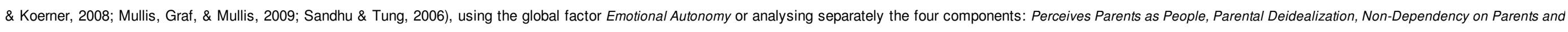
Individuation. For future work, we are aware of the need to include additional measures that take account of various aspects concerning the autonomy of adolescents and young adults.

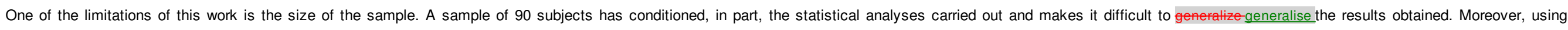

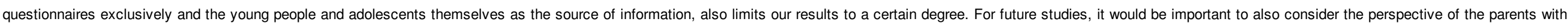

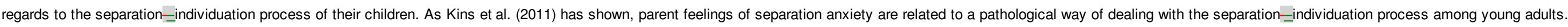

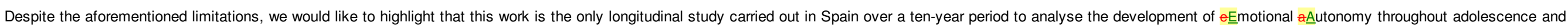

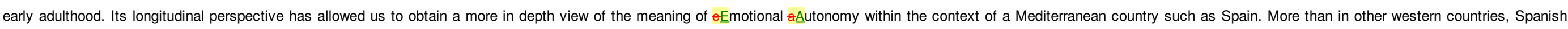

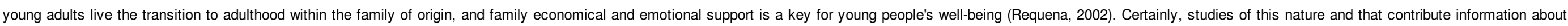
family relationships beyond adolescence are necessary, especially in non-Anglo-Saxon countries (Aquilino, 2006).

\section{References}

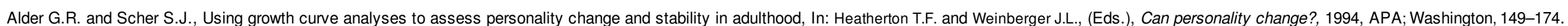

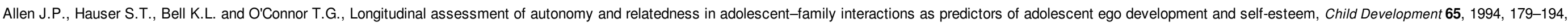
http://dx.doi.org/10.2307/1131374.

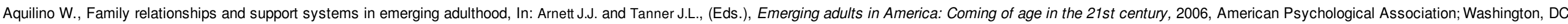
193-217.

Arnett J., Emerging adulthood: a theory of development from the late teens through the twenties, American Psychologist 55, 2000, 469-480, http://dx.doi.org/10.1037/0003-066X.55.5.469.

Arnett J., Emerging adulthood in Europe: a response to Bynner, Journal of Youth Studies 9, 2006, 111-123, http://dx.doi.org/10.1080/13676260500523671.

Barber B.K. and Buehler C., Family cohesion and enmeshment: different constructs, different effects, Journal of Marriage and the Family 1996, 433-441.

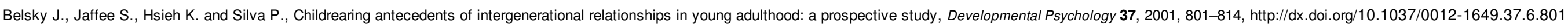




\section{elsevier_YJADO_1694}

Beyers W. and Goossens L., Psychological separation and adjustment to university: moderating effects of gender, age, and perceived parenting style, Journal of Adolescent Research 18, 2003, 363-382, http://dx.doi.org/10.1177/0743558403018004003.

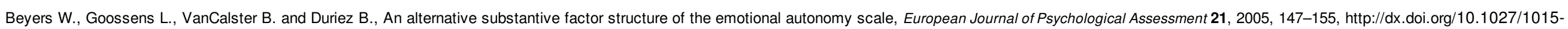
5759.21.3.147.

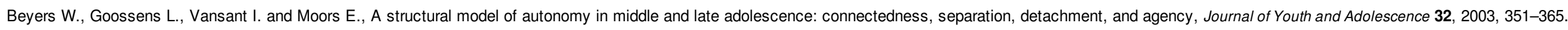
Blos P., The adolescent passage, 1979, The Free Press; New York.

Cohen J., Statistical power analysis for the behavioral science, 1988, Lawrence Erlbaum Associates; Hillsdale, EE.UU..

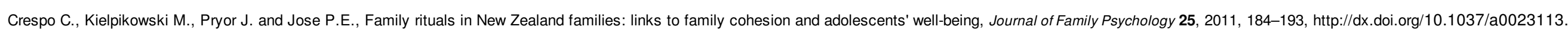

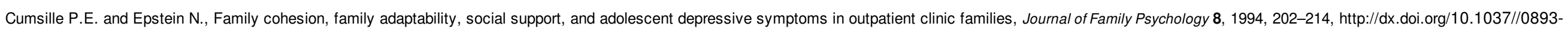
3200.8.2.202.

De Graaf H., van de Schoot R., Woertman L., Hawk S.T. and Meeus W., Family cohesion and romantic and sexual initiation: a three wave longitudinal study, Journal of Youth and Adolescence 41 (5), 2012, 583-592, http://dx.doi.org/10.1007/s10964-011-9708-9.

Fierro D. and Moreno A., Emerging adulthood in Mexican and Spanish youth: theories and realities, Journal of Adolescent Research 22, 2007, 476-503, http://dx.doi.org/10.1177/0743558407305774.

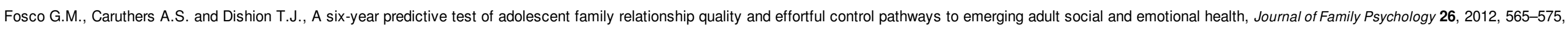
http://dx.doi.org/10.1037/a0028873.

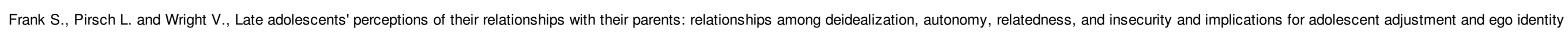
status, Journal of Youth and Adolescence 19, 1990, 571-588, http://dx.doi.org/10.1007/BF01537177.

Freud A., Adolescence, Psychoanalytic Study of the Child 13, 1958, 255-278.

Fuhrman T. and Holmbeck G.N., A contextual-moderator analysis of emotional autonomy and adjustment in adolescence, Child Development 66, 1995, 793-811, http://dx.doi.org/10.2307/1131951.

Garber J. and Little S.A., Emotional autonomy and adolescent adjustment, Journal of Adolescent Research 16, 2001, 355-371.

Grotevant H. and Cooper C., Individuation in family relationships: a perspective on individual differences in the development of identity and role-taking skill in adolescents, Human Development 29, 1986, 82-100.

Guisinger S. and Blatt S.J., Individuality and relatedness: evolution of a fundamental dialectic, American Psychologist 49, 1994, 104-111.

Hill J.P. and Holmbeck G., Attachment and autonomy in adolescence, In: Whitehurst G.J., (Ed), Annals of child development Vol. 3, 1986, JAI Press; Greenwich, CT, 145-189.

Huebner E.S., Correlates of life satisfaction in children, Social Psychology Quarterly 32, 1991, 254-259, http://dx.doi.org/10.1037/h0088805.

lacovou M. and Berthoud R., Young people's lives: A map of Europe, 2001, Institute of Social and Economic Research, Essex University; Colchester, UK.

Ingoglia S., Lo Coco A.L., Liga F. and Cricchio M.G.L., Emotional separation and detachment as two distinct dimensions of parent-adolescent relationships, International Journal of Behavioral Development 35, 2011,

271-281, doi:0165025410385878.

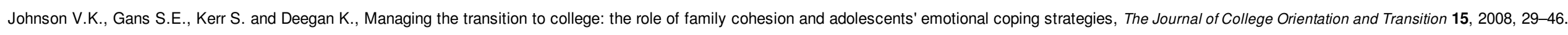

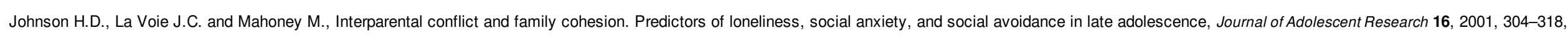

http://dx.doi.org/10.1177/0743558401163004. 
Kagitcibasi C., The autonomous-relational self: a new synthesis, European Psychologist 1, 1996, 180-186.

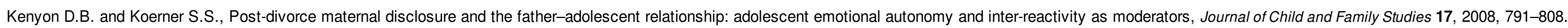

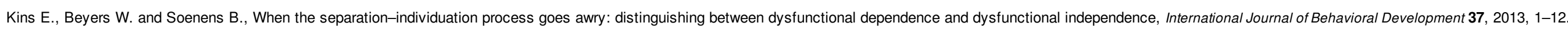

Kins E., Soenens B. and Beyers W., "Why do they grow up so fast?” Parental separation anxiety and emerging adults' pathology of separation-individuation, Journal of Clinical Psychology 67, $2011,647-664$.

Lamborn S. and Steinberg L., Emotional autonomy redux: revisiting Ryan and Lynch, Child Development 64, 1993, 483-499, http://dx.doi.org/10.2307/1131264.

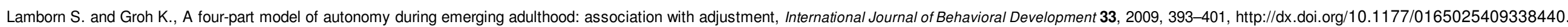

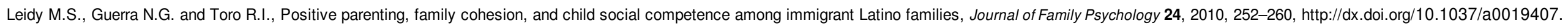

López S., The FACES II in the evaluation of family cohesion and adaptability, Psicothema 14, 2002, 159-166.

Manzi C., Regalia C., Pelucchi S. and Fincham F.D., Documenting different domains of promotion of autonomy in families, Journal of Adolescence 35, 2012, 289-298.

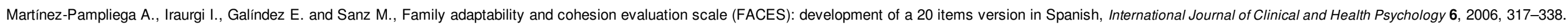
Minuchin S., Families and family therapy, 1974, Harvard University Press; Cambridge, MA.

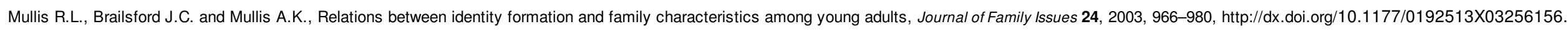

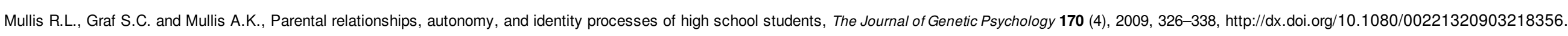
Noack P. and Buhl H.M., Relations with parents and friends during adolescence and early adulthood, Marriage \& Family Review 36, 2005, 31-51, http://dx.doi.org/10.1300/J002v36n03_03.

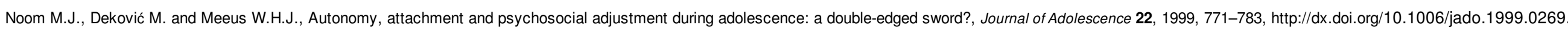
Oliva A. and Parra A., Autonomía emocional durante la adolescencia, [Emotional autonomy during adolescence], Infancia y Aprendizaje 24 (2), 2001, 181-196, http://dx.doi.org/10.1174/021037001316920726.

Olson D.H., Circumplex model of marital and family systems, Journal of Family Therapy 22, 2000, 144-167.

Olson D.H., Portner J. and Lavee Y., (Eds.), Family adaptability and cohesion scale, 1985, University of Minnesota; Minneapolis.

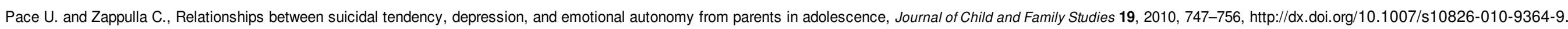

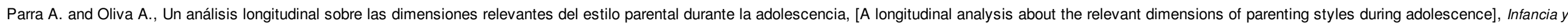
Aprendizaje 29, 2006, 453-470, http://dx.doi.org/10.1174/021037006778849594.

Parra A. and Oliva A., Comunicación y conflicto familiar durante la adolescencia, [Family communication and conflict during adolescence], Anales de Psicología 18 (2), 2002, 215-231.

Parra A. and Oliva A., A longitudinal research on the development of emotional autonomy during adolescence, The Spanish Journal of Psychology 12 (1), $2009,66-75$, http://dx.doi.org/10.1017/S1138741600001487.

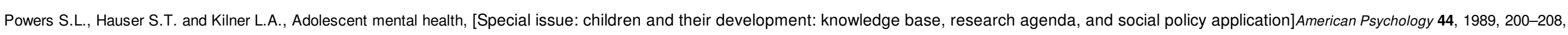
http://dx.doi.org/10.1037/0003-066X.44.2.200.

Preacher K.J., Calculation for the test of the difference between two independent correlation coefficients, [Computer software]. Available fromhttp://quantpsy.org 2002, May.

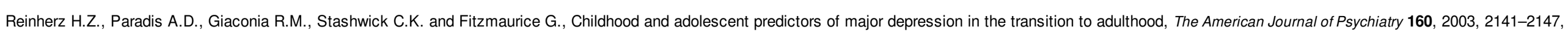
http://dx.doi.org/10.1176/appi.ajp.160.12.2141.

Requena M., Juventud y dependencia familiar en España, [Youth and family dependence in Spain], Revista de Estudios de Juventud 58, $2002,19-32$. 


\section{elsevier_YJADO_1694}

Roberts E.L. and Bengtson V.L., Relationships with parents, self-esteem, and, psychological well-being in young adulthood, Social Psychology Quarterly 56, 1993, 263-277, http://dx.doi.org/10.2307/2786663.

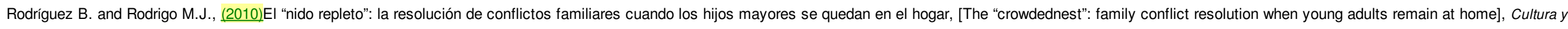
Educación 23 (1), 2011, 89-104, http://dx.doi.org/10.1174/113564011794728551.

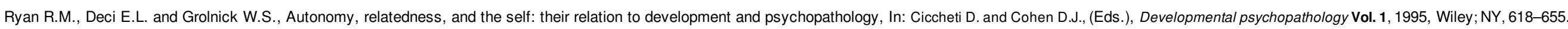

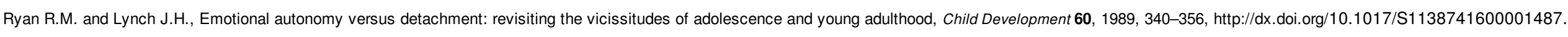

Sandhu D. and Tung S., Role of emotional autonomy and family environment in identity formation of adolescents, Pakistan Journal of Psychological Research 21, 2006, 1-16.

Scabini E., New aspects of family relations, In: Violato C. and Oddone-Paolucci E., (Eds.), The changing family and child development, 2000, Ashgate; Aldershot, UK, 3-24.

Scabini E., Marta E. and Lanz M., The transition to adulthood and family relations, 2006, Psychology Press; NY.

Schmitz M.F. and Baer J.C., The vicissitudes of measurement: a confirmatory factor analysis of the emotional autonomy scale, Child Development 72, 2001, 207-219, http://dx.doi.org/10.1111/1467-8624.00274.

Schnaiberg A. and Goldenberg S., From empty nest to crowded nest: the dynamics of incompletely-launched young adults, Social Problems 1989, 251-269.

Seiffge-Krenke I., "She's leaving home..." antecedents, consequences, and cultural patterns in the leaving home process, Emerging Adulthood 1, 2013, 114-124, http://dx.doi.org/10.1177/2167696813479783.

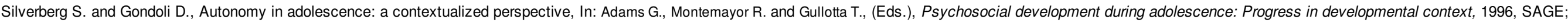

Thousand Oaks, CA, 12-61.

Smollar J. and Youniss J., Transformations in adolescents' perceptions of parents, International Journal of Behavioral Development 12, 1989, 71-84, http://dx.doi.org/10.1177/016502548901200104.

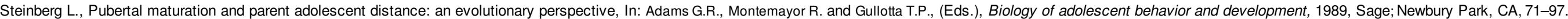
Steinberg L. and Silverberg S., The vicissitudes of autonomy in early adolescence, Child Development 57, 1986, 841-851, http://dx.doi.org/10.2307/1130361.

Stoolmiller M. and Bank L., Autoregressive effects in structural equation models: we see some problems, In: Gottnan J.M., (Ed), Analysis of change, 1995, Lawrence Erlbaum Associates; Mahwah, New Jersey, 261-278.

Thornton A., Orbuch T.L. and Axinn W.G., Parent-child relationships during the transition to adulthood, Journal of Family Issues 16, 1995, 538-564, http://dx.doi.org/10.1177/019251395016005003.

Tubman J.G. and Lerner R.M., Continuity and discontinuity in the affective experiences of parents and children: evidence from the New York longitudinal study, American Journal of Orthopsychiatry 64, 1994, 112-125,

http://dx.doi.org/10.1037/h0079488.

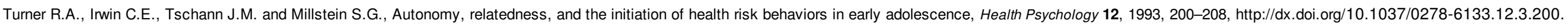

Umberson D., Relationships between adult children and their parents. Psychological consequences for both generations, Journal of Marriage and the Family 54, 1992, 664-674, http://dx.doi.org/10.2307/353252.

Wentzel K.R. and Feldman S.S., Relations of cohesion and power in family dyads to social and emotional adjustment during early adolescence, Journal of Research on Adolescence $\mathbf{2}$, 1996, 225-244.

Zimmer-Gembeck M.J. and Collins W.A., Autonomy development during adolescence, In: Adams G.R. and Berzonsky M., (Eds.), Blackwell handbook of adolescence, 2003 , Blackwell Publishers; Oxford, 175-204.

\section{Queries and Answers}

Query: Please check the hierarchy of the section headings.

Answer: ok

Query: Ref. "Rodriguez \& Rodrigo, 2010" is cited in the text but not provided in the reference list. Please provide it in the reference list or delete this citation from the text.

Answer: Ref Rodriguez \& Rodrigo was included in the reference list, but year 2010 was missing. 2010 is already included. 


\section{elsevier_YJADO_1694}

Query: Please check the doi number given in the reference "Ingoglia et al., 2011".

Answer: http://dx.doi.org/10.1177/0165025410385878

Query: Please confirm that given names and surnames have been identified correctly.

Answer: Names and surnames are correct. 